\title{
Logit Model of Computer-Based Data-Driven Creative Idea Generation in the Industry and Service Sectors
}

\author{
Sanaz Nikghadam Hojjati \\ Department of Information Technology Management \\ Science and Research Branch \\ Islamic Azad University \\ Tehran, Iran sanaznik@hotmail.com \\ Mahmood Alborzi \\ Department of Information Technology Management, \\ Science and Research Branch \\ Islamic Azad University \\ Tehran, Iran \\ mahmood_alborzi@yahoo.com
}

\author{
Ali Rajabzadeh Ghatari \\ Department of Management \\ Tarbiat Modares University \\ Tehran, Iran \\ alirajabzadeh@gmail.com
}

\author{
Gholamreza Hassanzadeh \\ Department of Anatomy, School of Medicine \\ Tehran University of Medical Sciences \\ Tehran, Iran \\ hassanzadeh@tums.ac.ir
}

\begin{abstract}
Organizational creativity and employee idea generation have become important and essential elements of an organization's success, as creativity results to increased performance. The need of increased creativity is evident in industrial and service companies. The main idea behind this paper is to analyze and demonstrate if accessing various types of data in certain ways and/or situations affects creative idea generation by the people involved in different industrial/service sectors, considering that now most of the employees use digital data. The current paper discusses how seven different factors are related to digital data affect creativity.
\end{abstract}

Keywords-idea; generation; computer-based; data-driven; creativity; competitive; environment; business

\section{INTRODUCTION}

In today's highly competitive environment the goal of each organization is to gain sustainable competitive advantage to defeat the competition and stabilize its operation [1]. Companies must create conditions for sustainable advantage under fierce competition. In [2] three conditions for sustainable advantage are indexed: 1) hierarchy of source, 2) number of distinct sources, and 3) constant improvement and upgrading. Organizational creativity is a means to build sustainable competitive advantage, among other things because it includes these three conditions. Creative thinking, idea generation and behavior is widely recognized as an important human skill and behavior in $21^{\text {st }}$ century [3-5]. Modern problems demand new forms of problem solving, and hence creativity becomes more important. While some companies do not give enough attention to creativity, a survey conducted by IBM, in which more than
1,500 CEOs from 60 countries and 33 industries were interviewed, showed that creativity is what is needed for success [6]. Creativity has also been defined as a key source for competitive advantages for long lasting organizations. In [7] it was showed that $82 \%$ of companies believe that there is a strong connection between creativity and business results. According to this report, companies that actively foster creative thinking outperform their rivals in revenue growth, market share and competitive leadership.

Modern accounts of creative cognition stress the central role of combining pre-existing knowledge components or materials [8]. Even exceptionally creative products have incorporated pre-existing material [9], such that some of these materials and components have never been used in relation to the subject matter. Awareness of the existence of these materials and/or components in different ways and in certain circumstances can help divergent thinking and creative idea generation [10-12]. Accordingly, accessing various data in different forms from their own specialized field along with data from other fields may help creative idea generation. In this regard, the present study intends to study the impact of accessing various data types in certain ways and situations on creative idea generation by people involved in different industrial/service sectors. It applies a logistic regression model and presents a logit model for these factors. The main contribution of this paper is therefore the discussion of how various types of data and ways of accessing it contribute to improve creativity. The empirical analysis presented here is based on a large sample of computer users and employs a set of explanatory variables. 


\section{THEORETICAL BACKGROUND}

\section{A. Creativity}

Creativity has been defined in different ways by different people [13, 43]. For instance, creativity was defined as a developing process for novel and imaginative views about different situations [14]. Some researchers state that creativity is the combining of ideas and individual and group approaches in a new way [15]. In [16] creativity is defined as a process composed of three main steps. The first step is becoming sensitive to problems, shortages, gaps in knowledge, pressures, lack of harmonies etc. The next step is finding new solutions for the previously identified problems as well as presenting hypotheses and testing them. In the last step the obtained results are communicated. Creativity covers different levels, from employee level to organizational level. This process encompasses employees being creative in their own work, which aid further development of the creative idea that is then passed through others to enhance the organization's creativity [17]. Therefore, understanding what causes creativity to flourish and what may inhibit it, is beneficial for organizations and a very important thematic for organizational research. Both personal and contextual factors [18] can affect creative performance, so organizational psychology has placed most of its focus on determining which factors promote creative ideas. On the one hand, there are many individual and organizational barriers to creativity [19-22]. On the other hand, organizational climate, culture, leadership, resources, skills, organizational structures and systems [23], inherent risk [24], job design [25, 26], support [27, 28], diversity [29, 30], safety [31, 32], resources [30,33], dynamics [31, 32], personal characteristics and individual [34-41], structural and system [23, 42] motivation can motivate individual, group and organizational creativity. Researchers in [11,13,27, 44] offered a theoretical perspective and understood creativity as the production or generation of novel and valuable ideas, products, or processes by individuals or groups. On the other hand, researchers' oriented to cognitive approach [45] offer a holistic vision of creativity, which includes non-cognitive factors (personal and social) in creative production. This approach views creative ideas as being the natural result of applying basic mental operations to existing knowledge structures. For instance, authors in [46] described and measured creativity by fluency, flexibility, originality and elaboration while and some others like editors in [47] emphasized the role of the environment, the person, and intrinsic motivation on creativity.

\section{B. Data and Creativity}

According to [48], knowledge and information are outcomes of human action that engages signs, signals, and artefacts in social and physical settings. Knowledge builds on an accumulation of experience and information, which depends on the data aggregation. Authors in [49] describe "data" as chunks of facts about the state of the world. They believe data may be either quantitative or qualitative in nature. When thinking of data most people seem to emphasize the quantitative form that is easily stored and manipulated in computer systems. Author in [50] reiterated that "data are material facts". Data, information, knowledge, and relative technologies have effect on creativity at all levels [51-59]. This is why these subjects became an interesting topic for individual, group and organizational creativity researchers (e.g. [60-83]). Authors in [60] have designed and implemented an innovative creativity support system. Authors in [74] considered the relation between computational creativity and computing. They stressed the important role of a knowledge base in creative computing system. Authors in [73] examined the relation between information technology use by children and their creativity. These researchers considered the use of 4 types of Information technology: 1) computer, 2) internet, 3) video games and 4) mobile. Authors showed that playing video games has a significant effect on children creative behaviour. The researchers suggested that video game designers should consider various aspects of stimulating creativity such as visual and audio features. Authors in [81] stated that creative work is often achieved in distributed groups. Therefore, information exchange is frequently facilitated by groupware systems. In order to reduce losses inherited in group work and to best support creative group processes (CGP), they proposed a framework which combines: a) the stages of the creative process, $b$ ) the potential losses of creative group processes and c) different media characteristics drawn from the Media Synchronicity Theory to formulate groupware design principles .Authors in [84-89], are among the researchers in the field of neurology and medicine that examined the effect of different data types (visual, audio and textual data) on human brain and its idea generation process.

\section{CONCEPTS AND APPROACH}

\section{A. Fundamental Concepts}

The seven fundamental concepts defined in the context of this work are:

- Various Visual Data (VVD)

- Various Textual Data (VTD)

- Various Audio Data (VAD)

- Data Related to the Performance of Various Creative Persons Who are Dealing with Similar Issues (DRC)

- Data Presentation Speed (DPS)

- Presentation of Various Data with Different Combinations and Various Arrangements, Frequently in a Variety of Time Periods (DPCAD)

- Presentation of Various Data to Users on the Left Side of the Screen so that the Left Eye Receives Them (PDLS)

Computer users from industrial or service companies deal with different data types which may affect creative idea generation in varying degrees. Thus, it is necessary to carefully define the data types considered. Computer users often interact with computer's output data using visual perception and auditory perception. The data received by eyesight is often separating into two different data types: visual and textual. The 
fundamental concept definition about three data types derives from this.

\section{1) Various Visual Data (VVD)}

Various visual data refer to a set of the offered data to the users in the form of images, charts, or movies. These types of data are recognized by users' visual perception. Patterns, trends and correlations that might go undetected in text-based data can be exposed and recognized easier with data visualization software.

\section{2) Various Textual Data (VTD)}

Various textual data refer to systematically collected material consisting of written, printed, or electronically published words, typically either purposefully written or transcribed from speech. These types of data are recognized by users' visual perception and demand reading and writing skills.

\section{3) Various Audio Data (VAD)}

Various audio data refer to a set of offered data to users through acoustic, frequencies, and they are commonly understandable by auditory human sense.

Computer users from industrial or service companies receive/process data with different content. Not all contents are suitable to improve creative idea generation. Thus, it is necessary to carefully define what data contents are being considered.

4) Data Related to the Performance of Various Creative Persons Dealing with Similar Issues (DRC)

Audio, visual and/or textual data presented to a user, which describe how other creative people performed similar activities, can conduct the behavior, feeling and thought of the user to be more creative.

\section{5) Data Presentation Speed (DPS)}

While sensitive to the speed of receiving data, the human brain reacts differently to data obtained at different speed, therefore it is necessary to carefully define the data presentation speed. Theoretically, humans' eyes and brain can perceive image and texts with a maximum speed of 1000 frames per second (FPS). However, to the untrained, this speed is commonly reduced to $150 \mathrm{FPS}$. In this research passing speed of various textual and visual data from human eyes is between 1 to 150 FPS.

6) Presentation of Various Data with Different Combination and Various Arrangements, Frequently in a Variety of Time Periods (DPCAD)

Different combinations and various arrangements of the received data can lead users to different understandings and different outcomes. Employees - computer users are frequently exposed to different combinations and various arrangements, frequently in a variety of time periods.

7) Presentation of Various Data to Users on the Left Side of the Screen so that the Left eye Receives These Data (PDLS)

Visual and textual placement in users' vision range can affect the user's perception. Computer users receive data in different visual range positions. Not all ranges are suitable to improve creative idea generation. To do this it is necessary to carefully define the vision range being considered. This variable refers to presenting various visual and textual data on the left side of the screen so that data are received outside the central vision (angle of 40 to 60 degrees) and the right half of the left eye much more than other places of both eyes.

\section{B. Approach}

The main question behind this research is if data type, content and properties effectively contribute to creative idea generation. One important issue to be discussed is why these seven data related factors were considered relevant enough for this study. It is consensual, that a data flood is created every day by the billions of people interactions using information and communication technologies. Researchers and policymakers are already realizing the potential of this torrent of data to identify needs, provide products and services, and predict and prevent crises for the benefits of individuals, organizations and societies. People need to access appropriate data in a specific situation and form in order to improve their ability of creative idea generation. Organizations which need to access creative ideas should provide and support appropriate data in a specific situation and form for their employees. Inappropriate data in inappropriate situation and form can prevent people, organizations and societies from accomplishing their goals [90]. Thus, identifying the appropriate type of data, the appropriate form and mixture of content, the appropriate way of presenting data and appropriate situations of presenting and accessing data are important in order to cause the generation of creative ideas for individual, organizational and social objectives.

\section{RESEARCH METHOD}

\section{A. Research Scheme}

This research is decision-oriented. The data collection method is a descriptive survey, and data analysis is correlational research. The dependent variable "Creative Idea Generation" is related to independent variables VVD, VTD, VAD, DRC, DPS, DPCAD, PDLS (see section III.A for definitions). These independent variables were chosen based on the literature. Table I indicates the research works supporting the choice of these independent variables. The theoretical framework for this research considers the following set of hypotheses:

- $\mathrm{H}_{1}$ : There is meaningful relationship between VVD and computer-based data-driven creative idea generation.

- $\mathrm{H}_{2}$ : There is meaningful relationship between VTD and computer-based data-driven creative idea generation.

- $\mathrm{H}_{3}$ : There is meaningful relationship between VAD and computer-based data-driven creative idea generation.

- $\mathrm{H}_{4}$ : There is meaningful relationship between DRC and computer-based data-driven creative idea generation.

- $\mathrm{H}_{5}$ : There is meaningful relationship between DPS and computer-based data-driven creative idea generation. 
- $\mathrm{H}_{6}$ : There is meaningful relationship between DPCAF and computer-based data-driven creative idea generation.

- $\mathrm{H}_{7}$ : There is meaningful relationship between PDLS and computer-based data-driven creative idea generation.

TABLE I. RESEARCHES THAT SUPPORT THE CONSIDERED INDEPENDENT VARIABLES

\begin{tabular}{|c|c|}
\hline Independent Variables & Researches Support Independent Variables \\
\hline VVD & {$[84],[87],[91],[92]$} \\
\hline VTD & {$[84],[87],[91],[92]$} \\
\hline VAD & {$[84],[87],[91],[92]$} \\
\hline DRC & {$[91],[93]$} \\
\hline DPS & {$[94],[95],[96]$} \\
\hline DPCAF & {$[91],[94],[95],[96]$} \\
\hline PDLS & {$[87],[91]$} \\
\hline
\end{tabular}

A questionnaire based on the theoretical framework indicated above was developed. It was designed to be answered on a Likert scale with a few demographic questions, and one cross-examination question placed between demographic questions. The study has a Cronbach's alpha coefficient of 0.713 indicating high reliability. The data were collected with an online questionnaire. An aspect worth to highlight is the large number of samples used, higher above the 384 that the Cochran formula considers as the minimum for unlimited community samples. The dependent variable is creative idea generation. Figure 1 displays the research variables and the related dimensions considered in the theoretical framework.

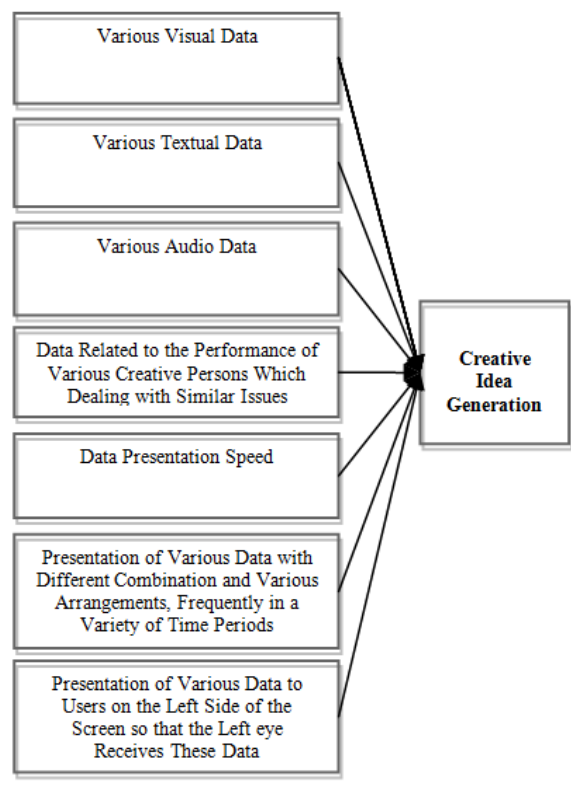

Fig. 1. Theoretical Framework

\section{B. Research participants}

To assess and validate the above hypotheses, two types of computer users from different domains were considered to fill the questionnaire: 1) industry/service, and 2) academics (university professors). The responses to this electronic questionnaire were anonymous and without any monetary incentives. The data was gathered in a time period of 6 months. A total of 929 individuals answered the questionnaire. The collected questionnaires were filtered in two stages:1) in the first stage the questionnaires whose participants did not answer all questions were removed, 2) in the second stage those questionnaires whose cross-examination question made the questionnaire unreliable were also removed. As a rule, if the difference between the answer of the cross-examination question and the answer of a dependent variable was more than 2 levels, then, that questionnaire was considered unreliable. Eventually, after this two-step screening we obtained 871 valid questionnaires.

\section{RESULTS}

\section{A. Descriptive Research Findings}

The number of participants for this study is 871 computer users of whom $60.8 \%$ were male and $39.2 \%$ female. The most prevalent age interval is the $21-30$ years old range with $42.1 \%$ of the participants. The data frequency distribution shows that $29.7 \%$ of the participants use computer and information systems daily for a period of 5-10 hours, while $22 \%$ use daily their computers for a period of 3-5 hours. Moreover, $78.1 \%$ of the users believe they are capable of creative idea generation while $21.9 \%$ believe they are not. Further details can be seen in Table II. Table III represents the descriptive analysis for dependent and independent variables. Frequency distribution of dependent variable data show that $30.1 \%$ of participants admit that "Sometimes" they generate computer-based data-driven creative ideas; $18.9 \%$ found it "Most of Times"; $17.1 \%$ "Very Rarely"; $16.9 \%$ "Rarely"; and finally, $7.2 \%$ of the participants in this research believed it happens "Always".

TABLE II. FREQUENCY DISTRIBUTION AND PERCENTAGES OF DEMOGRAPHIC VARIABLES

\begin{tabular}{|c|c|c|c|c|c|}
\hline & & Frequency & Percent & $\begin{array}{c}\text { Valid } \\
\text { Percent }\end{array}$ & $\begin{array}{c}\text { Cumula } \\
\text { tive } \\
\text { Percent }\end{array}$ \\
\hline \multirow{3}{*}{ Gender } & Female & 341 & 39.2 & 39.2 & 39.2 \\
\hline & Male & 530 & 60.8 & 60.8 & 100 \\
\hline & Total & 871 & 100 & 100 & \\
\hline \multirow{7}{*}{$\begin{array}{c}\text { Age } \\
\text { (Y.O.) }\end{array}$} & $<20$ & 31 & 3.6 & 3.6 & 3.6 \\
\hline & $21-3 \mathrm{O}$ & 367 & 42.1 & 42.1 & 45.7 \\
\hline & $31-40$ & 339 & 38.9 & 38.9 & 84.6 \\
\hline & $41-50$ & 114 & 13.1 & 13.1 & 97.7 \\
\hline & $51-60$ & 17 & 2.0 & 2.0 & 99.7 \\
\hline & $>60$ & 3 & 0.3 & 0.3 & 100 \\
\hline & Total & 871 & 100 & 100 & \\
\hline \multirow{7}{*}{$\begin{array}{l}\text { Comput } \\
\text { er and } \\
\text { Informa } \\
\text { tion } \\
\text { Systems } \\
\text { Usage } \\
\text { Per Day } \\
\text { (Hrs) }\end{array}$} & $<1$ & 111 & 12.7 & 12.7 & 18.6 \\
\hline & $1-3$ & 181 & 20.8 & 20.8 & 39.4 \\
\hline & $3-5$ & 192 & 22.0 & 22.0 & 61.4 \\
\hline & $5-10$ & 259 & 29.7 & 29.7 & 91.2 \\
\hline & $>10$ & 77 & 8.8 & 8.8 & 100 \\
\hline & No Idea & 51 & 5.9 & 5.9 & 5.9 \\
\hline & Total & 871 & 100 & 100 & 871 \\
\hline \multirow{3}{*}{$\begin{array}{l}\text { Creative } \\
\text { Idea } \\
\text { Generat } \\
\text { ion } \\
\text { Ability }\end{array}$} & Yes & 680 & 78.1 & 78.1 & 78.1 \\
\hline & No & 191 & 21.9 & 21.9 & 100 \\
\hline & Total & 871 & 100 & 100 & \\
\hline
\end{tabular}

YO: Years Old, Hr: Hours 
TABLE III. FREQUENCY DISTRIBUTION AND PERCENTAGES OF DEPENDENT AND INDEPENDENT RESEARCH VARIABLES

\begin{tabular}{|c|c|c|c|c|c|}
\hline & & Frequency & Percent & $\begin{array}{c}\text { Valid } \\
\text { Percent }\end{array}$ & $\begin{array}{c}\text { Cumulative } \\
\text { Percent }\end{array}$ \\
\hline & No Idea & 46 & 5.3 & 5.3 & 5.3 \\
\hline & Very Low & 147 & 16.9 & 16.9 & 22.2 \\
\hline & Low & 189 & 21.7 & 21.7 & 43.9 \\
\hline VVD & Middle & 295 & 33.9 & 33.9 & 77.7 \\
\hline & High & 157 & 18.0 & 18.0 & 95.8 \\
\hline & Very High & 37 & 4.2 & 4.2 & 100 \\
\hline & Total & 871 & 100 & 100 & \\
\hline & No Idea & 19 & 2.2 & 2.2 & 2.2 \\
\hline & Very Low & 66 & 7.6 & 7.6 & 9.8 \\
\hline & Low & 126 & 14.5 & 14.5 & 24.2 \\
\hline VTD & Middle & 259 & 29.7 & 29.7 & 54.0 \\
\hline & High & 310 & 35.6 & 35.6 & 89.6 \\
\hline & Very High & 91 & 10.4 & 10.4 & 100 \\
\hline & Total & 871 & 100 & 100 & \\
\hline & No Idea & 50 & 5.7 & 5.7 & 5.7 \\
\hline & Very Low & 316 & 36.3 & 36.3 & 42.0 \\
\hline & Low & 218 & 25.0 & 25.0 & 67.0 \\
\hline VAD & Middle & 181 & 20.8 & 20.8 & 87.8 \\
\hline & High & 88 & 10.1 & 10.1 & 97.9 \\
\hline & Very High & 18 & 2.1 & 2.1 & 100 \\
\hline & Total & 871 & 100 & 100 & \\
\hline & No Idea & 78 & 9.0 & 9.0 & 9.0 \\
\hline & Very Low & 204 & 23.4 & 23.4 & 32.4 \\
\hline & Low & 252 & 28.9 & 28.9 & 61.3 \\
\hline DRC & Middle & 228 & 26.2 & 26.2 & 87.5 \\
\hline & High & 97 & 11.1 & 11.1 & 98.6 \\
\hline & Very High & 12 & 1.4 & 1.4 & 100 \\
\hline & Total & 871 & 100 & 100 & \\
\hline & No Idea & 53 & 6.1 & 6.1 & 6.1 \\
\hline & Very Low & 77 & 8.8 & 8.8 & 14.9 \\
\hline & Low & 149 & 17.1 & 17.1 & 32.0 \\
\hline DPS & Middle & 413 & 47.4 & 47.4 & 79.4 \\
\hline & High & 152 & 17.5 & 17.5 & 96.9 \\
\hline & Very High & 27 & 3.1 & 3.1 & 100 \\
\hline & Total & 871 & 100 & 100 & \\
\hline & No Idea & 100 & 11.5 & 11.5 & 11.5 \\
\hline & Very Few & 106 & 12.2 & 12.2 & 23.7 \\
\hline & Few & 206 & 23.7 & 23.7 & 47.3 \\
\hline DPCAF & Middle & 307 & 35.2 & 35.2 & 82.5 \\
\hline & High & 125 & 14.4 & 14.4 & 96.9 \\
\hline & Very High & 27 & 3.1 & 3.1 & 100 \\
\hline & Total & 871 & 100 & 100 & \\
\hline & No Idea & 143 & 16.4 & 16.4 & 16.4 \\
\hline & Very Low & 126 & 14.5 & 14.5 & 30.9 \\
\hline & Low & 224 & 25.7 & 25.7 & 56.6 \\
\hline PDLS & Middle & 241 & 27.7 & 27.7 & 84.3 \\
\hline & High & 118 & 13.5 & 13.5 & 97.8 \\
\hline & Very High & 19 & 2.2 & 2.2 & 100 \\
\hline & Total & 871 & 100 & 100 & \\
\hline & No Idea & 85 & 9.8 & 9.8 & 9.8 \\
\hline & Very Rarely & 149 & 17.1 & 17.1 & 26.9 \\
\hline & Rarely & 147 & 16.9 & 16.9 & 43.7 \\
\hline CIG* & \begin{tabular}{|l} 
Sometimes \\
\end{tabular} & 262 & 30.1 & 30.1 & 73.8 \\
\hline & $\begin{array}{c}\text { Most of } \\
\text { Times }\end{array}$ & 165 & 18.9 & 18.9 & 92.8 \\
\hline & Always & 63 & 7.2 & 7.2 & 100 \\
\hline
\end{tabular}

\section{B. Results of Analytical Research}

Since the sample size of this study is large ( 871 persons), the distribution of data is normal (Note: Based on Central Limit
Theory plus some simulations if sample size is bigger than 30 $(\mathrm{N} \geq 30)$ then sample is assumed as "large sample" and the sampling distribution is considered normal [97]). Given that this distribution is normal for all variables in the society, the Pearson correlation coefficient was used to analyze the relationship between variables. The results of computing the correlation coefficient between the variables are shown in Table IV. Given that the "Sig" is less than the significance level (0.01), significant relationship between the variables in the model is proved. To analyze the impact of each independent variable to predict the dependent variable linear regression equation for the relationships outlined in the model is calculated. According to Table V, the Durbin-Watson $\mathrm{d}=$ 1.764 is between the two critical values of $1.5<\mathrm{d}<2.5$ and therefore we can assume that there is no first order linear autocorrelation in the data. Also, we found that the adjusted $\mathrm{R}^{2}$ of our model is 0.237 with the $\mathrm{R}^{2}=0.244$ that means that the linear regression explains $24.4 \%$ of the variance in the data.

TABLE IV. PEARSON CORRELATION TEST FOR RESEARCH VARIABLES

\begin{tabular}{|c|c|c|}
\hline \multicolumn{2}{|r|}{ Correlations } & Creative Idea Generation \\
\hline \multirow{3}{*}{ VVD } & Pearson Correlation & $0.365^{* *}$ \\
\hline & Sig. (2-tailed) & 0.000 \\
\hline & $\mathrm{N}$ & 871 \\
\hline \multirow{3}{*}{ VTD } & Pearson Correlation & $0.312^{* *}$ \\
\hline & Sig. (2-tailed) & 0.000 \\
\hline & $\mathrm{N}$ & 871 \\
\hline \multirow{3}{*}{ VAD } & Pearson Correlation & $0.098^{* *}$ \\
\hline & Sig. (2-tailed) & 0.004 \\
\hline & $\mathrm{N}$ & 871 \\
\hline \multirow{3}{*}{ DRC } & Pearson Correlation & $0.360^{\text {** }}$ \\
\hline & Sig. (2-tailed) & 0.000 \\
\hline & $\mathrm{N}$ & 871 \\
\hline \multirow{3}{*}{ DPS } & Pearson Correlation & $0.215^{* *}$ \\
\hline & Sig. (2-tailed) & 0.000 \\
\hline & $\mathrm{N}$ & 871 \\
\hline \multirow{3}{*}{ DPCAF } & Pearson Correlation & $0.243^{* *}$ \\
\hline & Sig. (2-tailed) & 0.000 \\
\hline & $\mathrm{N}$ & 871 \\
\hline \multirow{3}{*}{ PDLS } & Pearson Correlation & $0.234^{* *}$ \\
\hline & Sig. (2-tailed) & 0.000 \\
\hline & $\mathrm{N}$ & 871 \\
\hline
\end{tabular}

TABLE V. MODEL SUMMARY TABLE

\begin{tabular}{|c|c|c|c|c|c|}
\hline Model & $\mathbf{R}$ & $\mathbf{R}^{2}$ & Adjusted $\mathbf{R}^{2}$ & $\begin{array}{c}\text { Std. Error of the } \\
\text { Estimate }\end{array}$ & Durbin-Watson \\
\hline 1 & 0.493 & 0.244 & 0.237 & 1.233 & 1.764 \\
\hline
\end{tabular}

This low $\mathrm{P}$ value / high $\mathrm{R}^{2}$ combination indicates that changes in the predictors are related to changes in the response variable and that their model explains a lot of the response variability. The explanation for this rather high $\mathrm{R}^{2}$ is that, like most human related studies, some factors like genetic, environmental, cultural and economic ones were de facto not considered. Also, one has to remember that people are unpredictable. If this research was to consider all the things that might affect someone's creative idea generation it would be expected for these seven special variables to be minor contributors. Putting all possible factors into the model would 
indeed give better results. But the goal of this research was to see if there was a small, but reliable relationship between the specific variables and the creative idea generation. Small effect sizes require larger samples to find significance which is the case of this research, as it involved the participation of 871 users. Table VI indicates the F-test. The linear regression's Ftest has the null hypothesis that there is no linear relationship between the two variables (in other words $\mathrm{R}^{2}=0$ ). With $\mathrm{F}=$ 39.685 and 863 degrees of freedom the test is highly significant, thus we can assume that there is a linear relationship between the variables in our model

Table VII shows the regression coefficients, the intercept and the significance of all coefficients and the intercept in the model. We find that our linear regression analysis estimates the linear regression function to be:

$0.443+0.228(V V D)+0.127(V T D)-0.107(V A D)$ $+0.274(D R C)+0.097(D P S)+0.083(D P C A F)+0.128(P D L S)$ $=\mathrm{y}$

In Table VII, the coefficients for the variables are shown. All have p-value smaller than 0.05. The intercept is significantly different from 0 at the 0.05 alpha levels.

TABLE VI. THE LINEAR REGRESSION'S F-TEST

\begin{tabular}{|c|c|c|c|c|c|c|}
\hline \multicolumn{7}{|c|}{ ANOVA } \\
\hline \multicolumn{2}{|c|}{ Model } & Sum of Squares & df & Mean Square & F & Sig. \\
\hline \multirow{2}{*}{1} & Regression & 421.993 & 7 & 60.285 & 39.685 & 0.000 \\
\cline { 2 - 8 } & Residual & 1310.951 & 863 & 1.519 & & \\
\cline { 2 - 8 } & Total & 1732.944 & 870 & & & \\
\hline
\end{tabular}

TABLE VII. SIMPLE LINEAR REGRESSION COEFFICIENTS

\begin{tabular}{|c|c|c|c|c|c|c|}
\hline \multicolumn{7}{|c|}{ Coefficients $^{\mathrm{a}}$} \\
\hline & \multirow[t]{2}{*}{ Model } & \multicolumn{2}{|c|}{$\begin{array}{c}\text { Unstandardized } \\
\text { Coefficients }\end{array}$} & \multirow{2}{*}{$\begin{array}{c}\begin{array}{c}\text { Standardized } \\
\text { Coefficients }\end{array} \\
\text { Beta } \\
\end{array}$} & \multirow[t]{2}{*}{$\mathbf{t}$} & \multirow[t]{2}{*}{ Sig. } \\
\hline & & B & Std. Error & & & \\
\hline \multirow{8}{*}{1} & (Constant) & 0.443 & 0.155 & & 2.857 & 0.004 \\
\hline & VVD & 0.228 & 0.041 & 0.199 & 5.625 & 0.000 \\
\hline & VTD & 0.127 & 0.042 & 0.106 & 3.034 & 0.002 \\
\hline & VAD & -0.107 & 0.038 & -0.090 & -2.806 & 0.005 \\
\hline & DRC & 0.274 & 0.041 & 0.231 & 6.757 & 0.000 \\
\hline & DPS & 0.097 & 0.040 & 0.078 & 2.461 & 0.014 \\
\hline & DPCAF & 0.083 & 0.036 & 0.075 & 2.276 & 0.023 \\
\hline & PDLS & 0.128 & 0.033 & 0.121 & 3.861 & 0.000 \\
\hline
\end{tabular}

\section{CONCLUSION}

The main idea behind this paper was to analyze and demonstrate if accessing various types of data in certain ways and situations affects creative idea generation in people involved in different areas of the industry and services. As computer-based data-driven creativity becomes more and more recognized as one key factor for long term organization and business sustainability the present study contributes to understanding if various types and forms of data can improve the sustainability of computer related tasks in industry. Considering the importance of data in current societies it was considered relevant to analyze if this environmental factor was effectively improving creativity. To verify this relation, a questionnaire was developed with answers using the Likert scale. To make the study more credible the chosen target population were highly skilled computer users for two main reasons:

- Computer users are much more familiar with various data types in certain ways and situations than most of other population

- Most of creative industrial/services jobs are using intensively computers nowadays, so most of target creative population are computer users

The findings from the questionnaires showed that the defined variables have a positive and meaningful relationship with creative idea generation, demonstrating the validity of Hypotheses 1 to 7 defined in the Research Method section (Section III.A). Moreover, the variable "Various Audio Data" (VAD) has a negative and meaningful relationship with creative idea generation, indicating in this way the validity of the Hypothesis 3 defined in the Research Method section (Section III.A). Like most other research, this one is not complete and several limitations that need to be solved in future work are indicated below:

- Only three separated general types of data (visual, textual and audio data) were considered as types of data in this research. It is also recognized that adding more specific types of data may contribute to creative idea generation. However, it was decided to focus on these three general types because of their widespread usage in today's organizational computer systems.

- On the data content, only those contents that were related to the performance of various creative persons which were dealing with similar issues were considered. However, it is still necessary to investigate if other types of contents can indoctrinate and encourage creative idea generation between employees or provide clues for motivating divergent thinking or out of the box thinking for improving creative idea generation processes.

- The authors only considered if various data with different combinations and various arrangements, will impact a creative idea generation. But, they did not discuss the kind of data, the combination, arrangement and frequency. Thus, future research must address these issues.

- The validation by the end users was mainly qualitative in the sense that their answers were based on their individual perception and not on real quantitative data. The main aspect here is that when users were answering if factors improved their creativity they answered based on qualitative perception and not on data that measure quantitatively how effectively they became more creative.

Despite these limitations the fundamental conclusions from this work are:

- Research departments should encourage the use of VVD, DRV and VTD to improve creativity. On the other hand, DPS, DPCAF, PDLS and VAD have little importance. The 
use of various audio data (VAD) is even not recommendable.

- There are business opportunities for companies to develop new applications targeting specifically creative idea generation following the identified aspects discussed in this paper.

- The results obtained with this work are important to increase the competitive advantage of companies and their survival in today's dynamic and complex business environment.

\section{REFERENCES}

[1] J. B. Barney, Gaining and sustaining competitive advantage, Pearson Education, 2014

[2] M. Porter, The Competitive Advantage of Nations, Free Press, 1990

[3] K. F. Geisinger, "21st Century Skills: What Are They and How Do We Assess Them?", Applied Measurement in Education, Vol. 29, No. 4, pp. 245-249, 2016

[4] S. Metz, "21st-century skills.(Editor's Corner: Notes From the Field Editor)(technology and science education)(Editorial)", The Science Teacher, Vol. 78, No. 7, pp. 6, 2011

[5] K. Ananiadou, M. Claro, 21st century skills and competences for new millennium learners in OECD countries, OECD Publishing, No. 41, OECD Education Working Papers, 2009

[6] S. Tomasco, IBM 2010 Global CEO Study:Creativity Selected as Most Crucial Factor for Future Success, Available at: https://www03.ibm.com/press/us/en/pressrelease/31670.wss, 2017

[7] Forrester Consulting, The Creative Dividend: How Creativity Impacts Business Results, Forrester Research, Inc, 2014

[8] R. A. Finke, T. B. Ward, S. M. Smith, Creative cognition: Theory, research, and applications, MIT Press, 1992

[9] M. A. Boden, The Creative Mind: Myths and Mechanisms, Weidenfield and Nicholson, 1990

[10] D. K. Simonton, Origins of genius: Darwinian perspectives on creativity, University Press, 1999

[11] T. M. Amabile, Creativity in context: update to The social psychology of creativity,Westview Press, 1996

[12] M. E. Sosa, "Where do creative interactions come from? The role of tie content and social networks", Organization Science, Vol. 22, No. 1, pp. $1-21,2011$

[13] M. L. Gruys, N. V. Munshi, T. C. Dewett, "When antecedents diverge: Exploring novelty and value as dimensions of creativity", Thinking Skills and Creativity, Vol. 6, No. 2, pp. 132-137, 2011

[14] R. W. Griffin, G. Moorhead, Organizational bahaviour: Managing People and Organizations, Cengage Learning, 2009

[15] T. B. Ward, S. M. Smith, R. A. Finke, "Creative Cognition", in Handbook of Creativity, R. J. Sternberg, Cambridge University Press, 1998, pp. 189-212

[16] E. P. Torrance, The Torrance Tests of Creative Thinking-NormsTechnical Manual Research Edition-Verbal Tests, Forms A and BFigural Tests, Forms A and B, Personnel Press, 1966

[17] C. E. Shalley, J. Zhou, G. R. Oldham, "The Effects of Personal and Contextual Characteristics on Creativity: Where Should We Go from Here?", Journal of Management, Vol. 30, No. 6, pp. 933-958, 2004

[18] J. Zhou, C. E. Shalley, Handbook of Organizational Creativity, Taylor \& Francis Group, 2008

[19] M. Edwards-Schachter, A. García-Granero, M. Sanchez-Barrioluengo, H. Quesada-Pineda, N. Amara, "Disentangling competences: Interrelationships on creativity, innovation and entrepreneurship", Thinking Skills and Creativity, Vol. 16, pp. 27-39, 2015

[20] L. K. Gundry, L. F. Ofstein, J. R. Kickul, "Seeing around corners: How creativity skills in entrepreneurship education influence innovation in business", The International Journal of Management Education, Vol. 12, No.3, pp. 529-538, 2014

[21] G. Davis, "Barriers to creativity and creative attitudes", in Encyclopedia of Creativity, M. A. Runco, S. R. Pritzker, Academic Press, pp. 115 121,2011

[22] E. J. Jung, S. Lee, "The combined effects of relationship conflict and the relational self on creativity", Organizational Behavior and Human Decision Processes, Vol. 130, pp. 44-57, 2015

[23] C. Andriopoulos, "Determinants of organizational creativity: a literature review", Management Decision, Vol. 39, No. 10, pp. 834- 840, 2001

[24] R. J. Sternberg, L. A. O'Hara, T. I. Lubart, "Creativity as investment", California Management Review Vol. 40, No. 1, pp. 8-21, 1997

[25] J. L. Farr, Facilitating individual role innovation, Jone Wiley and Sons Ltd, 1990

[26] A. Cummings, G. R. Oldham, "Enhancing creativity: Managing work contexts for the high potential employee", California Management Review, Vol. 40, No. 1, pp. 22-38, 1997

[27] J. Zhou, J. M. George, "When job dissatisfaction leads to creativity: Encouraging the expression of voice", Academy of Management journal, Vol. 44, No. 4, pp. 682-696, 2001

[28] G. Ekvall, "Organizational Climate for Creativity and Innovation", European Journal of Work \& Organizational Psychology, Vol. 5, No. 1, pp. 105-123, 1996

[29] L. Cummings, "Organizational Climates for Creativity", The Academy of Management Journal, Vol. 8, No. 3, pp. 220-227, 1965

[30] T. M. Amabile, "How to kill creativity", Harvard Business Review, Vol. 76, pp. 76-87, 1998

[31] N. Anderson, G. Hardy, M. West, "Management Team Innovation", Management Decision, Vol. 30, No. 2, 1992

[32] G. Dutton, "Enhancing creativity", Management Review, Vol. 85, No. 11,1996

[33] S. Ohly, S. Sonnentag, F. Pluntke, "Routinization, work characteristics and their relationships with creative and proactive behaviors", Journal of Organizational Behavior, Vol. 27, No. 3, pp. 257-279, 2006

[34] F. Barron, "Putting creativity to work", in The nature of creativity, R. J. Sternberg, Cambridge University Press, pp. 76-98, 1988

[35] E. P. Torrance, "The Nature Of Creativity As Manifest In Its Testing", in The Nature of Creativity, R. J. Sternberg, Cambridge University Press, 1988

[36] B. A. Hennessey, T. M. Amabile, "The conditions of creativity", in The nature of creativity, R. J. Sternberg, Cambridge University Press, 1988

[37] H. A. Walberg, "Creativity and talent as learning", in The nature of creativity, R. J. Sternberg, Cambridge University Press, pp. 340-361, 1988

[38] R. J. Sternberg, "A three-facet model of creativity", in The nature of creativity, R. J. Sternberg, Cambridge University Press, pp. 125-147, 1988

[39] M. Reddy Sarsani, Creativity In Schools, Sarup \& Sons, 2005

[40] T. M. Amabile, "Within you, without you: The social psychology of creativity and beyond", in Theories of creativity, M. A. Runco, R. S. Albert, Sage, pp. 61-91, 1990

[41] F. B. Barron, D. M. Harrington, "Creativity, intelligence, and personality", Annual Review of Psychology, Vol. 32, pp. 439-476, 1981

[42] S. Williams, "Increasing employees' creativity by training their managers", Industrial and Commercial Training, Vol. 33, No. 2, pp. 6368, 2001

[43] R. E. Mayer, "Fifty Years of Creativity Research", in Handbook of creativity, R. J. Sternberg, Cambridge University Press, pp. 449-460, 1999

[44] G. R. Oldham, A. Cummings, "Employee creativity: Personal and contextual factors at work", Academy of Management Journal, Vol. 39, No. 3, pp. 607-634, 1996

[45] T. B. Ward, "Cognition, creativity, and entrepreneurship", Journal of Business Venturing, Vol. 19, No. 2, pp. 173-188, 2004 
[46] L. S. Almeida, L. P. Prieto, M. Ferrando, E. Oliveira, C. Ferrandiz, "Torrance Test of Creative Thinking: The question of its construct validity", Thinking Skills and Creativity, Vol. 3, No. 1, pp. 53-58, 2008

[47] T. M. Amabile, The social psychology of creativity, Springer-Verlag, 1983

[48] C. W. Choo, Information Management for the Intelligent Organization: The Art of Scanning the Environment, Information Today Inc, 2002

[49] P. R. Gamble, J. Blackwell, Knowledge Management: A State of the Art Guide, Kogan Page Publishers, 2001

[50] B. Boiko, Content Management Bible, John Wiley \& Sons, 2005

[51] S. E. Caplan, Problematic internet use in the workplace, Armonk, 2006

[52] K. Dibben, "Hi-tech crime: phones hit by virus", The Sunday mail, 28 June, p. 27, 2009

[53] T. Abraham, L. W. Boone, "Computer-Based Systems and Organizational Decision Making: An Architecture to Support Organizational Innovation", Creativity Research Journal, Vol. 7, No. 2, pp. 111-123, 1994

[54] J. R. Evans, Creative Thinking in the Decision and Management Sciences, South-Western Publishing, 1991

[55] S. Winship, "Packages Stimulate Creative Process, Buyers Say", PC Week, Vol. 23, pp. 109-110, 1991

[56] A. Van Gundy, IdeaPower, American Management Association, 1992

[57] G. M. Marakas, J. J. Elam, "Creativity enhancement in problem solving: through software or process?", Management Science, Vol. 43, No. 8, pp. 1136-1146, 1997

[58] D. Dayton, "Idea Generators Spark New Solutions", PC Week, March 18, pp. 109-110, 1991

[59] L. Young, Decision Support and Idea Processing Systems, WC Brown, 1989

[60] D. Siemon, T. Rarog, S. Robra-Bissantz, "Semi-Automated Questions as a Cognitive Stimulus in Idea Generation", 49th Hawaii International Conference on System Sciences, 2016

[61] A. Gabriel, D. Monticolo, M. Camargo, M. Bourgault, "Creativity Support Systems: A Systematic Mapping Study", Thinking Skills and Creativity Vol. 21, pp. 109-122, 2016

[62] F. Ulrich, "A Group Creativity Support System for Dynamic Idea Evaluation", Sixth Scandinavian Conference on Information Systems, pp. 137-151, 2015

[63] F. Ulrich, Imagination from Evaluation: A Design Theory for Creativity Enhancing, PhD Thesis, Aalborg Universitetsforlag, 2016

[64] C. M. Olszak, J. Kisielnicki, "Organizational Creativity and IT-based Support", Informing Science: the International Journal of an Emerging Transdiscipline, Vol. 19, pp. 103-123, 2016

[65] P.-J. Cheng, "Development of a mobile app for generating creative ideas based on exploring designers' on-line resource searching and retrieval behavior", Design Studies, Vol. 44 pp. 74-99, 2016

[66] G. R. Oldham, N. Da Silva, "The impact of digital technology on the generation and implementation of creative ideas in the workplace", Computers in Human Behavior, Vol. 42 pp. 5-11, 2015

[67] K. Muldner, W. Burleson, "Utilizing sensor data to model students' creativity in a digital environment", Computers in Human Behavior Vol. 42, pp. 127-137, 2015

[68] L. S. Chechurin, W. W. Wits, H. M. Bakker, "Invention software support by integrating function and mathematical modeling", Chemical Engineering Research and Design, Vol. 103, pp. 32-39, 2015

[69] A. Ivanov, D. Cyr, "Satisfaction with outcome and process from webbased meetings for idea generation and selection: The roles of instrumentality, enjoyment, and interface design", Telematics and Informatics Vol. 31, No. 4, pp. 543-558, 2014

[70] M. Voigt, K. Bergener, J. Becker, "Comprehensive Support for Creativity-Intensive Processes", Business \& Information Systems Engineering, Vol. 5, No. 4, pp. 227-242, 2013

[71] M. Voigt, "Improving Design of Systems Supporting Creativityintensive Processes-A Cross-industry Focus Group Evaluation", Communications of the Association for Information Systems Vol. 34, Article No 86, 2014
[72] M. Voigt, B. Niehaves, J. Becker, "Towards a unified design theory for creativity support systems", in K. Peffers, M. Rothenberger, B. Kuechler, Design Science Research in Information Systems. Advances in Theory and Practice, Springer, 2012

[73] L. A. Jackson, E. A. Witt, A. I. Games, H. E. Fitzgerald, A. von Eye, Y. Zhao, "Information technology use and creativity: Findings from the Children and Technology Project", Computers in Human Behavior, Vol. 28 , No. 2, pp. 370-376, 2012

[74] L. R. Varshney, F. Pinel, K. R. Varshney, A. Schorgendorfer, Y. M. Chee, "Cognition as a part of computational creativity", 12th IEEE International Conference on Cognitive Informatics \& Cognitive Computing , pp. 36-43, 2013

[75] S. D. Muller, F. Ulrich, "Creativity and information systems in a hypercompetitive environment: A literature review", Communications of the Association for Information Systems, Vol. 32, pp. 175-201, 2013

[76] S. Vijayarani, S. Radjamanogary, "Motivating Employees Creativity through Suggestion System - An Empirical Study", Journal of Business and Management Vol. 9, No. 2, pp. 22-27 2013

[77] V. Santos, L. Amaral, H. Mamede, "Information Systems Planning-How to Enhance Creativity?", International Conference on ENTERprise Information Systems, Springer, pp. 398-407, 2011

[78] F. Muller-Wienbergen, O. Müller, S. Seidel, J. Becker, "Leaving the beaten tracks in creative work-a design theory for systems that support convergent and divergent thinking", Journal of the Association for Information Systems, Vol. 12, No. 11, pp. 714-740, 2011

[79] S. Seidel, F. Müller-Wienbergen, J. Becker, "The Concept of Creativity in the Information Systems Discipline: Past, Present, and Prospects", Communications of the Association for Information Systems, Vol. 27, pp. 217-242, 2010

[80] H. Yuhashi, I. Junichi, "The Power to Activate a Creative Core in Enterprise", Pacific Asia Journal of the Association for Information Systems, Vol. 2, No. 2, 2010

[81] J. Becker, K. Bergener, M. Voigt, "Supporting Creative Group Processes: Design Principles for Appropriate Groupware", 2010 European Conference on Information Systems, Paper 34, 2010

[82] F. Forster, "Improving creative thinking abilities using a generic collaborative creativity support system", Research, reflections and innovations in integrating ICT in education, pp. 539-543, 2009

[83] T. T. Hewett, "Informing the design of computer-based environments to support creativity", International Journal of Human-Computer Studies , Vol. 63, No. 4-5, pp. 383-409, 2005

[84] E. G. Chrysikou, R. H. Hamilton, H. B. Coslett, A. Datta, M. Bikson, S. L. Thompson-Schill, "Noninvasive Transcranial Direct Current Stimulation Over the Left Prefrontal Cortex Facilitates Cognitive Flexibility in Tool Use", Cognitive Neuroscience, Vol. 4, No. 2, pp. 8189, 2013

[85] B. Baird, J. Smallwood, M. D. Mrazek, J. W. Kam, M. S. Franklin, J. W. Schooler, "Inspired by Distraction :Mind Wandering Facilitates Creative Incubation", Psychological Science, Vol. 23, No. 10, pp. 1117-1122, 2012

[86] R. Mehta, R. J. Zhu, "Blue or Red? Exploring the Effect of Color on Cognitive Task Performances", Science, Vol. 323, pp. 1226-1229, 2009

[87] M. Jung-Beeman, E. M. Bowden, J. Haberman, J. L. Frymiare, S. Arambel-Liu, R. Greenblatt, P. J. Reber, J. Kounios, "Neural Activity When People Solve Verbal Problems with Insight", PLoS Biology, Vol. 2, No. 4, pp. 500-510, 2004

[88] C. Limb, A. Braun, "Neural Substrates of Spontaneous Musical Performance: An fMRI Study of Jazz Improvisation", PLoS ONE, Vol. 3, No. 2, pp. e1679, 1-9, 2008

[89] S. Liu, H. M. Chow, Y. Xu, M. G. Erkkinen, K. E. Swett, M. W. Eagle, D. A. Rizik-Baer, A. R. Braun, "Neural Correlates of Lyrical Improvisation: An fMRI Study of Freestyle Rap", Scientific Reports 2, Article No 834, 2012

[90] C. Bowern, Linguistic Fieldwork - A Practical guide, Palgrave Macmillan, 2008 
[91] J. W. Schooler, S. Ohlsson, K. Brooks, "Thoughts beyond words: When language overshadows insight", Journal of Experimental Psychology: General, Vol. 122, No. 2, pp. 166-183, 1993

[92] D. Offner, "“'Hitch-Hiking” on Creativity in Nature”, The Journal of Creative Behavior, Vol. 24, No. 3, pp. 199-204, 1990

[93] T. Kramer, L. G. Block, "Like Mike: Ability contagion through touched objects increases confidence and improves performance", Organizational Behavior and Human Decision Processes, Vol. 124, No. 2, pp. 215-228, 2014

[94] R. Jung, How are intelligence and creativity related to brain structure and function?, Available at: http://www.rexjung.com/, 2015
[95] R. Jung, B. S. Mead, J. Carrasco, R. A. Flores, "The structure of creative cognition in the human brain", Frontiers in Human Neuroscience, Vol. 7, p. 330,2013

[96] R. E. Jung, R. Grazioplene, A. Caphrihan, R. S. Chavez, R. J. Haier, "White Matter Integrity, Creativity, and Psychopathology: Disentangling Constructs with Diffusion Tensor Imaging”, PLoS ONE, Vol. 5, No. 3, pp. $1-7,2010$

[97] R. V. Hogg, E. A. Tanis, D. L. Zimmerman, Probability and statistical inference, Pearson Education, 2015 